\title{
Properties Of Analyst Forecasts And Bond Underwriting Relationship: Evidence From Korea
}

\author{
Seong Ho Bae, Kyungpook National University, South Korea \\ Seok Woo Jeong, Korea University, South Korea \\ Woo Jae Lee, Chungnam National University, South Korea \\ Kwangwuk Oh, Korea University, South Korea
}

\begin{abstract}
Previous studies find that analysts forecast earnings more optimistically but inaccurately when they face the conflict of interest (COI). We extend this line of research by examining whether analysts' forecasting behavior affected by the mere existence of potential COI are related with underwriting contracts.

We document that analysts affiliated with security companies that become underwriters ex post issue more optimistic but less accurate forecasts for firms to issue bonds in Korea. We also find that firms to issue bonds are likely to award underwriting contracts to security companies with analysts who issue more optimistic but less accurate forecasts.
\end{abstract}

Keywords: Analysts’ Forecast Bias; Analysts’ Forecast Accuracy; Underwriting Contract; Bond Issuance

\section{INTRODUCTION}

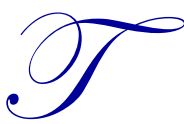

he purpose of this paper is to investigate whether analysts are affected by the existence and magnitude of potential conflict of interest (here after 'COI') in forecasting earnings and whether firms intending to issue bonds are affected by analysts' aggressive forecasting behavior in choosing underwriters. Prior studies show that analysts make more optimistic but less accurate earnings forecasts or favorable stock recommendation when they face the COI (Dugar \& Nathan, 1995; Lin \& McNichols, 1998; Michaely \& Womack, 1999; Hodgkinson 2001; Jeong, Kim \& Lim, 2006; Ljungqvist, Marston \& Wilhelm, 2006; Chan, Karceski \& Lakonishok, 2007). However, few studies such as Ljungqvist et al. (2006) have analyzed whether the possibility of getting stock underwriting contracts and expected underwriting contract fees affect analysts' behavior and, in return, whether actual underwriting contracts are affected by analysts' forecasts. Ljungqvist et al. (2006) analyze whether analysts issue more optimistic forecasts when they face the potential COI and the expected benefits from the potential $\mathrm{COI}$ are large, and document consistent results with their expectation. But they obtained mixed results about the effect of ex-ante analysts' optimistic forecasts on underwriting contracts.

In this study, we extend this line of research by examining the issues in Ljungqvist et al. (2006) in the bond market. This study examines how analysts forecast in general when they may face the COI. Even though many previous studies have analyzed forecasts and recommendations of analysts who already face the COI, few studies have examined how analysts are affected in general when the potential COI exists. That is, no studies have examined forecast properties by analysts who may face the COI but eventually do not. Most studies have focused on analysts' forecasting behavior when analysts already face the COI, even when they analyze analysts' behavior before they make underwriting contracts. Further, many previous studies in this area focused more on analysts in the stock market. However, participants in the bond market may have different decision-making problems and thereby use information differently (Holthausen \& Watts, 2001) and the optimism in forecasts may be bigger in the bond market. This suggests that analysts issuing forecasts for firms intending to issue bonds are likely to have a different degree of COI from for firms intending to issue stocks. Therefore, it would be an interesting and important question for investors to know how 
analysts are affected in the bond market where accounting information differently affects market participants from the stock market.

Further, the bond market has two different attributes from stock markets: i.e., transactions are less frequent in the secondary market and primary market participants are institutional investors. These two characteristics make analysts' forecasts less important in the bond market than in the stock market, because market participants in bond markets are more likely to rely less on public information such as analysts' forecasts in their decision making than those in stock markets, which implies the smaller cost of inaccurate forecasting for analysts. In addition, market share in the bond underwriting market and prior bond underwriting relationship with firms to bonds are considered as underwriters' ability to help firms issue bonds on favorable terms (Ljungqvist et al. 2006). Therefore, it is very important for security companies to get imminent underwriting contracts from firms intending to issue bonds, even when they have to further sacrifice the accuracy of earnings forecasts because it will increase the possibility of getting future underwriting contracts. This incentive provides an environment for security companies to pressure their analysts to make more optimistic but less inaccurate forecasts for firms intending to issue bonds.

To summarize, analysts who make forecasts for firms intending to issue bonds face a smaller cost of inaccurate forecasts and security companies have strong incentives to get imminent underwriting contracts. Therefore, security companies are more likely to pressure their analysts to issue more optimistic but less accurate forecasts for firms intending to issue bonds. Analysts affiliated with security companies are likely to issue more optimistic forecasts for bond issuing firms because their forecasts are intended for a few institutional investors rather than many investors in the public and because the unfavorable effect due to optimistic but inaccurate forecasts on analysts' reputation and affiliated companies is relatively smaller (weaker) in the bond market than in the stock market (Cowen, Groysberg \& Healy, 2006). Further, firms intending to issue bonds are also more likely to make underwriting contracts with security firms whose affiliated analysts issue more optimistic forecasts because they want to issue bonds on the most favorable terms.

We analyze 13,588 earnings forecasts for firms that issued bonds between 2000 and 2008 before underwriting contracts in Korea to address our research questions. The study results are as follows. First, analysts affiliated with security firms that had underwriting contracts ex post issued more optimistic but less accurate forecasts before underwriting contracts than non-affiliated analysts who also issued more optimistic but less accurate forecasts in general. This result suggests affiliated analysts are more affected by incentives that firms intending to issue bonds give or pressures underwriting security companies may give to their analysts. Second, regardless of ex post affiliation, analysts issued more optimistic but less accurate forecasts for firms with a larger amount of bond issuance. This further implies that analysts are affected more by the magnitude of expected benefits such as underwriting fees and future underwriting contracts. In addition, ex post affiliated analysts issued more optimistic but less accurate forecasts ex ante for firms with a larger amount of bond issuance than non-affiliated analysts who also issued more optimistic forecasts for firms intending to issue a larger amount of bonds than for other firms intending to issue bonds. Third, the optimism and inaccuracy of the forecasts were maximized around the time of deciding the underwriting companies. This result reinforces our conjectures that the analysts' incentives to increase the possibility of gaining underwriting contracts lead analysts to issue more optimistic but less accurate forecasts. This result was robust even after controlling for other variables which may have affected the attributes of analysts' forecasts, such as analysts' experience, resources available for analysts, and firm characteristics. Fourth, the increased optimism and inaccuracy of analysts' forecasts were significantly and positively related with the choice of underwriting contracts, suggesting that security companies that have analysts who issue more optimistic but less accurate forecasts are more likely to be awarded underwriting contracts by firms intending to issue bonds.

These study results have the following contributions to the existing literature in this area. First, we explicitly identify the effect of potential COI that analysts face in the bond market on analysts' forecasts. Most prior papers have shown the effect of COI on analysts' forecasts by comparing affiliated analysts' forecasts with non-affiliated forecasts after analysts face the COI (Dugar \& Nathan, 1995; Lin \& McNichols, 1998; Jeong et al., 2006). By analyzing forecasts made before underwriting contracts, we show that all analysts working for security companies with a chance to be underwriters generally issue more optimistic but less accurate forecasts and that this tendency increases for affiliated analysts. That is, non-affiliated analysts also issue more optimistic but less accurate forecasts for firms intending to issue bonds than for firms not issuing bonds. Different from prior studies that did not document the effect of COI on 
short-term forecasts in the stock market, we document that the COI caused in the bond market significantly affects short-term forecasts.

Third, differently from prior studies that did not find a significant relation between underwriting contracts and the optimism in the forecasts, we show that underwriting contracts are partly affected by the optimism in the analysts' forecasts. Further, our results suggest that investors in the stock market need to take into consideration the degree of optimism in analysts' forecasts for bond issuing firms when they make investment decisions for bond-issuing firms based on analysts' forecasts.

The rest of the paper is organized as follows. Section 2 describes prior studies and the hypothesis development. Section 3 provides research methods and sample selection procedures. The analysis results are presented in Section 4. Section 5 explains the conclusions and limitations.

\section{LITERATURE REVIEW AND HYPOTHESIS}

Analysts can adjust earnings' forecasts in response to various situations that create economic incentives. Economic compensation and analysts' reputation can create incentives for analysts to bias their forecasts and sell-side analysts are known to increase their compensation by providing favorable forecasts to boost trading activities. Many previous studies also show that analysts are affected by the COI when they make earnings forecasts or stock recommendations (Dugar \& Nathan, 1995; Lin \& McNichols, 1998; Michaely \& Womack, 1999; Dechow, Hutton \& Sloan, 2000; Jeong et al., 2006; Ljungqvist et al., 2006, \& Chan et al., 2007).

Dugar and Nathan (1995) compare forecasts for firms with underwriting contracts by analysts affiliated with investment bankers with non-affiliated analysts using Investment Banker lists in Corporate Finance Bluebook between 1983 and 1988 and find that analysts' forecasts affiliated with investment bankers are more optimistic and favorable. Using 2,400 seasoned equity offerings between 1989 and 1994, Lin and McNichols (1998) analyze short-term earnings forecasts, long-term growth forecasts, and stock recommendations by analysts affiliated with investment bankers and report that analysts affiliated with investment bankers do favorably forecast long-term growth for firms under underwriting contracts and recommend them while they do not issue more favorable short-term forecasts for firms under underwriting contracts. Michaely and Womack (1999) find underwriting contracts make analysts issue more optimistic recommendations than other analysts after IPO by investigating 391 IPOs in 1990 and 1991. Jeong et al. (2006) document that analysts who work in security companies belonging to business groups issue more favorable earnings forecasts and stock recommendations for firms belonging to the same business groups in Korea. Dechow et al. (2000) also show that analysts affiliated with underwriters issue more optimistic but less accurate long-term growth forecasts. Ljungqvist et al. (2006) also examine whether analysts bias their forecasts, are more aggressive when potential fee income from investment banking services is larger, and analysts' behavior increases the likelihood of getting underwriting contracts. Consistent with previous studies, they report that analysts affiliated with investment bankers issue favorable forecasts and become more aggressive when potential fee income is larger, but do not find any evidence that the chance of getting underwriting contracts has been increased by analysts' aggressive behavior. Chan et al. (2007) examine whether analysts tied to investment banking adjust earnings forecasts immediately prior to earnings announcements enough to match or exceed actual earnings and document that forecast error distribution is shifted prior to earnings announcement in favor of firms, suggesting that analysts revise earnings forecasts to help managers.

We address our research question in the bond market. While accounting information under GAAP provides useful information for various kinds of decision makers, such as debt security investors, creditors, clients, employees, and stock investors, information about credit such as bankruptcy possibility and solvency (debt repaying ability) is more useful for bond investors, which is different from stock equity investors (Holthausen \& Watts ,2001; Watts 2003). Because the possibility of repayment of principal and interest is the most important consideration for bonds, bond investors may consider that information such as the severity of financial difficulties, liquidity, and solvency is more important in bond-related decision making than the future prospects of firms. That is, bond investors are more concerned about bond issuing firms' inability to repay and the lower limit of net asset value (Watts 2003). Therefore, information about future growth potential or firm value increase due to firms' business prospects may be less useful 
in the bond market than in the stock market (Holthausen \& Watts 2001), implying that the kind of useful information may differ across different markets and decision-making problems.

This suggests the need to analyze the characteristics and usefulness of accounting information examined in the stock market in different markets, such as the bond market. Further, different from stock markets, large institutional investors are primary market participants for bonds. Institutional investors such as investment trust companies and pension funds can easily raise a large amount of capital. Even when underwriting companies sell bonds which they have to directly take from bond issuing companies at the time of issuance, most of these bonds are also purchased by institutional investors (Kim, Kim, Woo \& Lee, 2009). That is, market participants in the bond market are primarily institutional investors, while those in the primary stock market are primarily individual investors. In addition, because there are not many market participants in the bond market, transactions are less frequent than in the stock market, which prevents inaccurate earnings forecasts in the bond market from hurting analysts' reputation as much as in the stock market. Further, security companies may need to take a different approach to access the market in order to secure underwriting contracts, because bond issuances are less frequent than stock issuances. When managers have more private information about firms, they prefer to raise capital via debts to stocks (Grinblatt \& Titman 1998). Specifically, because inaccurate forecasts may hurt analysts' reputation less in the bond market than in the stock market, and because the economic incentives that analysts may face in the bond market could be affected by different factors (Das, Levine \& Sivaramakrishnan, 1998; Cowen et al., 2006; Ljungqvist et al., 2006), analysts are more likely to provide favorable forecasts which reflect the bond market characteristics.

As documented in prior studies for forecasts after the COI is known and based on the above discussion, we expect analysts affiliated with underwriters to issue more optimistic forecasts than non-affiliated analysts. Therefore, our first hypothesis is as follows.

Hypothesis 1: Ex ante earnings forecasts issued by ex post affiliated analysts with security companies for firms intending to issue bonds are more optimistic and less accurate than those issued by ex post non-affiliated analysts.

In the case of large expected benefits from underwriting contracts, analysts are more likely to be affected by the magnitude of the expected benefits and we expect analysts who are affiliated with security companies that become underwriters to issue more optimistic and less accurate forecasts. Therefore, our second and third hypotheses are as follows.

Hypothesis 2: Ex ante analysts' forecasts are more optimistic and less accurate for a larger amount of bond issuance.

Hypothesis 3: Ex ante earnings forecasts issued by ex post affiliated analysts for firms intending to issue a larger amount of bonds are more optimistic and less accurate than those issued by ex post non-affiliated analysts.

We also examine the question of whether underwriting contracts are influenced by biases in analysts' forecasts. Even though Ljungqvist et al. (2006) and Chan et al. (2007) examine whether analysts are influenced by the desire to win underwriting contracts in their forecasts, they do not provide evidence that underwriting contracts are positively related to the biases in affiliated analysts' forecasts. Because the cost of inaccurate forecasts is expected to be smaller for analysts in the bond market, we set our final hypothesis as follows.

Hypothesis 4: Firms intending to issue bonds are more likely to award bond underwriting contracts to security firms whose analysts issue ex ante more optimistic but less accurate forecasts for firms intending to issue bonds.

\section{RESEARCH METHODOLOGY}

As discussed in the previous section, we address four empirical questions: (1) whether ex post affiliated analysts' forecasts are more biased or less accurate than non-affiliated analysts' forecasts for firms intending to issue bonds, (2) whether the amount of bond to be issued has a significant impact on analysts' forecast properties, (3) whether affiliated analysts' forecasts are more biased or less accurate in proportion with the amount of bond to be issued, and (4) whether firms intending to issue bonds are affected by the degree of optimism in analysts' forecasts in awarding underwriting contracts. To test for our research questions, we regress the properties of analysts' forecasts, measured by bias and 
accuracy of analysts' forecasts, against underwriting contract dummy, amount of bond to be issued and other control variables that potentially affect analysts' forecasts, as follows.

$$
\begin{aligned}
& \text { BIAS (or ACCU) }=\alpha_{0}+\alpha_{1} U N W R T_{i, t}+\alpha_{2} M A G N I_{i, t}+\alpha_{3} \operatorname{SIZE}_{i, t}+\alpha_{4} L E V_{i, t}+\alpha_{5} V O L_{i, t}+\alpha_{6} B M_{i, t}+\alpha_{7} R O E_{i, t} \\
& +\alpha_{8} D A Y G A P_{i, t}+\text { Industry_Fixed }+ \text { Year_Fixed }+\varepsilon \\
& B I A S(\text { or ACCU })=\beta_{0}+\beta_{1} U N W R T_{i, t}+\beta_{2} M A G N I_{i, t}+\beta_{3}(U N W R T \times M A G N I)_{i, t}+\beta_{4} S I Z E_{i, t}+\beta_{5} L E V_{i, t} \\
& +\beta_{6} V O L_{i, t}+\beta_{7} B M_{i, t}+\beta_{8} R O E_{i, t}+\beta_{9} D A Y G A P_{i, t}+\text { Industry_Fixed }+ \text { Year_Fixed }+v \\
& \text { UNWRT(1 or 0) }=\beta_{0}+\beta_{1} \operatorname{Bias}(\text { Accuracy })_{i, t}+\beta_{2} H O U S E_{-} M S_{i, t}+\beta_{3} S A M E_{-} H S_{i, t}+\beta_{4} H O U S E \_A S T_{i, t} \\
& + \text { Industry_Fixed }+ \text { Year_Fixed }+v
\end{aligned}
$$

where: $i$ denotes firm, $t$ denotes years for FY 2000 FY2008, BIAS is the difference between actual and forecasted earnings divided by market value of equity measured at three months after fiscal year end, $A C C U$ is the absolute value of $B I A S, B O N D$ is a dummy variable that equals ' 1 ' if firms intend to issue bonds in year t, UNWRT is a dummy variable that equals ' 1 ' if analysts are affiliated with security companies which become underwriter for firms intending to issue bonds, MAGNI is the amount of bond to be issued, scaled by market value of equity, SIZE is a natural logarithm of total assets, $L E V$ is leverage measured by dividing total liabilities with total assets, $V O L$ is the volatility of daily stock price, $B M$ is book-to-market ratio calculated by dividing net book value by market value of equity, $R O E$ is return on equity, and DAYGAP is a natural logarithm of number of days from forecast reporting to issuance of bond. HOUSE_MS is the 3 year-average underwriting amount of bond by the security company to which an analyst belongs. $S A M E \_\bar{H} S$ is a dummy variable that equals ' 1 ' if a security company has experience of providing underwriting services to firms intending to issue bonds during the previous 3 -years ${ }^{1}$. HOUSE_AST is the total assets of a security company.

From models (1) to (3), dependent variables are earnings forecast bias $(B I A S)$ and accuracy $(A C C U)$. Following prior studies, we calculate $B I A S$ as the difference between actual earnings before extra-ordinary items and forecasted earnings scaled with market value of equity 3-months after fiscal year-end (Dugar \& Nathan, 1995; Lin \& McNichols, 1998; Jeong et al., 2006; Ahn, Yoo, Cho, Shin \& Chang, 2006), and $A C C U$ as the unsigned difference between actual and forecasted earnings divided by market value of equity.

In models (1) and (2), the coefficients on $U N W R T$ indicate the differences in forecast properties between non-affiliated and affiliated analysts. Prior studies show that the incentive to raise future economic benefits by being nominated as an underwriter can force analysts who are affiliated with security companies that provide underwriting services to issue more optimistic but less accurate forecasts. Hence, if our conjecture is right, we expect that the coefficient estimates on $U N W R T$ for $B I A S(A C C U$ ) are significantly negative (positive).

The amount of bonds to be issued (MAGNI) can influence analysts to issue more optimistic but less accurate forecasts for firms intending to issue bonds, regardless of underwriting contracts. In models (1) and (2), the coefficients on $M A G N I$ can be interpreted as the degree of general influence over analysts' forecasts from the economic incentive created by the amount of bond to be issued. In addition, we can interpret that the coefficients on $U N W R T \times M A G N I$ show the difference in optimism of forecasts between affiliated analysts and non-affiliated analysts due to economic incentives caused by the amount of bond to be issued. We expect that the coefficients on MAGNI and on $U N W R T \times M A G N I$ for $B I A S(A C C U)$ are significantly negative (positive).

We use firm size (SIZE), leverage ( $L E V)$, volatility $(V O L)$, book-to-market ratio $(B M)$, return on equity $(R O E)$, and the horizon $(D A Y G A P)$ as control variables based on prior literature. SIZE is considered to proxy many causes such as variation in information environment, complexity and the degree of competition among analysts which affect analysts' forecasts (Bhushan, 1989; Duru \& Reeb, 2002; Gu \& Wu, 2003). Bhushan (1989) documents that large firms have more analyst followings and that analysts' forecasts for large firms are likely to be less biased and more accurate

\footnotetext{
${ }^{1}$ We calculated HOUSE_MS for 2001(2000) as 2-year (1 year) average underwriting amount of bond by the security company to which an analyst belongs. SAME_HS for 2003 and 2002 equals ' 1 ' if we can observe that a security company has experience of providing underwriting service to firms to issue bonds during the previous 2 years and 1 year, respectively. For 2000, we assume $S A M E \_H S$ as ' 0 ' because the initiation date of the sample is inevitably censored. To check the consistency of our results, we re-estimated our models with 10,754 observations (2003 2008) and untabulated results illustrate that the incorporation of reduced samples into the models does not significantly change our findings.
} 
because large firms have rich information environment. However, Duru and Reeb (2002) argue that SIZE indicates more complexity and thus induces greater forecast errors. Das et al. (1998) argue that analysts have stronger incentive to issue more optimistically to facilitate access to information for less predictable firms. Further, $\mathrm{Gu}$ and $\mathrm{Wu}$ (2003) argue that if SIZE is positively correlated with analyst following, it can lead to more intensive competition among analysts and document that analysts issue more biased and less accurate forecasts for large company, to earn managers' favor more. Because the prior literature indicates mixed results for the effect of size on analysts' forecasts, we do not clearly predict the sign on SIZE. Because $L E V$ is known to be positively correlated with upward earnings manipulation (Healy \& Wahlen 1999), we predict negative (positive) coefficient estimates on $L E V$ for BIAS (ACCU). The volatility of stock return is expected to be positively correlated with forecasts' bias and inaccuracy because the volatility of business projects operated by firms decreases the predictability of future earnings. When uncertainty is larger in forecasting earnings, analysts are more likely to issue biased and less accurate reports (Lee \& Jeong 1993; Duru \& Reeb 2002; Jeong 2003; Ahn et al. 2006; Han, Joo \& Kim, 2005). Thus, we expect return VOL to be negatively (positively) related to BIAS ( $A C C U$ ). We include $B M$ and $R O E$ to control the tendency on the forecast for firms with good future prospects (Francis \& Willis 2000; Gu \& Wu 2003; Han et al. 2005) and expect positive (negative) coefficient estimates on $B M$ and ROE for BIAS (ACCU), respectively. Kang, O'Brien \& Sivaramakrishnan, (1994) and Das et al. (1998) show that analysts forecast more optimistically for longer horizons. To control for this, we include a natural logarithm of days from forecast to issuance date (DAYGAP). Finally, we include dummy variables to control for industry and calendar year effects.

In model (3), we expect the coefficients on $B I A S$ ( $A C C U$ ) to be significantly negative (positive), because firms intending to issue bonds also want to make underwriting contracts with security companies whose affiliated analysts issue more optimistic but less accurate forecasts. It is more likely that security companies whose affiliated analysts issue more optimistic but less accurate forecasts will offer firms intending to issue bonds favorable terms of bond issuance. We also control variables known to affect the choice of underwriter in prior studies. Ljungqvist et al. (2006) show that the market share in the underwriting contract market (HOUSE_MS) and the past experience of providing underwriting services to firms intending to issue bonds (SAME_HS) are the two primary factors that affect the decision of underwriters. Luo, Rao \& Yue, (2010) also show that underwriter reputation affects the choice of underwriter by firms. The market share of underwriting contracts is considered to represent the general ability of security companies to provide underwriting services and the past experience of providing underwriting services indicates the specific knowledge (ability) of security companies to provide underwriting services to firms intending to issue bonds. We expect both variables are significantly positively related with the choice of underwriters (UNWRT). Furthermore, we include total assets of security companies (HOUSE_AST) as an additional control variable because the resources of security companies are considered as the general ability of providing underwriting services. We also expect the positive coefficient on this variable as two other control variables.

\section{SAMPLES AND DESCRIPTIVE STATISTICS}

\subsection{Sample}

We use listed firms in the stock market in Korea (Korea Stock Exchange, KSE and Korea Securities Dealers Automated Quotation, KOSDAQ) and initially collect data for firms that issued corporate bonds from 2000 to 2008. We retrieve financial data, corporate bond data and analysts' forecast data from KIS-Value Library and Fn-Guide ${ }^{2}$, respectively. For firms intending to issue bonds, only analyst forecasts prior to bond issuance date are retrieved. From the initial sample, we delete firms in the financial industry and non-December fiscal year-end firms. For the tests of hypotheses 1 to 3, we use forecasts only for firms intending to issue bonds by affiliated and non-affiliated analysts. Forecasts that meet our sample selection criteria are 12,496 individual non-affiliated analysts' forecasts (1,260 nonaffiliated analysts in 240 houses) and 1,092 individual affiliated analysts' reports (151 affiliated analysts in 78 houses) for 186 firms who newly issued corporate bonds.

\footnotetext{
${ }^{2}$ KIS-Value Library and Fn-Guide provide financial statement and analysts' forecasts data and are compatible with Compustat and I/B/E/S in the U.S, respectively. 
Table 1. Sample Distribution

\begin{tabular}{|c|c|c|c|c|c|c|c|c|c|}
\hline \multirow{2}{*}{$\begin{array}{l}\text { Fiscal } \\
\text { Year }\end{array}$} & \multicolumn{4}{|c|}{ Non-affiliated [UNWRT $=0$ ] } & \multicolumn{4}{|c|}{ Affiliated [UNWRT $=1]$} & \multirow{2}{*}{$\begin{array}{c}\text { Total } \\
\text { \#Forecast } \\
{[\%]}\end{array}$} \\
\hline & $\begin{array}{c}\text { \#Forecast } \\
{[\% \text { ] }}\end{array}$ & \# House & \#Analyst & \# Firms & $\begin{array}{c}\text { \#Forecast } \\
\text { [ \% ] }\end{array}$ & \# House & \#Analyst & \# Firms & \\
\hline 2000 & $\begin{array}{c}363 \\
{[2.67 \%]}\end{array}$ & 20 & 53 & 32 & $\begin{array}{c}60 \\
{[0.44 \%]}\end{array}$ & 6 & 9 & 32 & $\begin{array}{c}423 \\
{[3.11 \%]}\end{array}$ \\
\hline 2001 & $\begin{array}{c}1,453 \\
{[10.69 \%]}\end{array}$ & 27 & 107 & 30 & $\begin{array}{c}167 \\
{[1.23 \%]}\end{array}$ & 9 & 19 & 30 & $\begin{array}{c}1,620 \\
{[11.92 \%]}\end{array}$ \\
\hline 2002 & $\begin{array}{c}718 \\
{[5.28 \%]}\end{array}$ & 27 & 95 & 14 & $\begin{array}{c}73 \\
{[0.54 \%]}\end{array}$ & 8 & 12 & 14 & $\begin{array}{c}791 \\
{[5.82 \%]}\end{array}$ \\
\hline 2003 & $\begin{array}{c}862 \\
{[6.34 \%]}\end{array}$ & 29 & 148 & 15 & $\begin{array}{c}74 \\
{[0.54 \%]}\end{array}$ & 8 & 16 & 15 & $\begin{array}{c}936 \\
{[6.89 \%]}\end{array}$ \\
\hline 2004 & $\begin{array}{c}2,356 \\
{[17.34 \%]}\end{array}$ & 30 & 247 & 24 & $\begin{array}{c}204 \\
{[1.50 \%]}\end{array}$ & 11 & 26 & 24 & $\begin{array}{c}2,560 \\
{[18.84 \%]}\end{array}$ \\
\hline 2005 & $\begin{array}{c}2,380 \\
{[17.52 \%]}\end{array}$ & 29 & 181 & 18 & $\begin{array}{c}190 \\
{[1.40 \%]}\end{array}$ & 10 & 18 & 18 & $\begin{array}{c}2,570 \\
{[18.91 \%]}\end{array}$ \\
\hline 2006 & $\begin{array}{c}1,850 \\
{[13.61 \%]}\end{array}$ & 25 & 116 & 11 & $\begin{array}{c}108 \\
{[0.79 \%]}\end{array}$ & 8 & 10 & 11 & $\begin{array}{c}1,958 \\
{[14,41 \%]}\end{array}$ \\
\hline 2007 & $\begin{array}{c}905 \\
{[6,66 \%]}\end{array}$ & 25 & 146 & 20 & $\begin{array}{c}92 \\
{[0.68 \%]}\end{array}$ & 8 & 20 & 20 & $\begin{array}{c}997 \\
{[7.34 \%]}\end{array}$ \\
\hline 2008 & $\begin{array}{c}1,609 \\
{[11.84 \%]}\end{array}$ & 28 & 167 & 22 & $\begin{array}{c}124 \\
{[0.91 \%]}\end{array}$ & 10 & 21 & 22 & $\begin{array}{c}1,733 \\
{[12,75 \%]}\end{array}$ \\
\hline Total & $\begin{array}{c}12,496 \\
{[91.96 \%]}\end{array}$ & 240 & 1,260 & 186 & $\begin{array}{c}1,092 \\
{[8.04 \%]}\end{array}$ & 78 & 151 & 186 & $\begin{array}{c}13,588 \\
{[100.00 \%}\end{array}$ \\
\hline
\end{tabular}

\#Forecast is the number of report observations, \#House is the number of houses that issued analysts' report, and \#Firms is the number of firms that issued corporate bond

\subsection{Descriptive Statistics}

Panels A and B of Table 2 provide the descriptive statistics and overall difference of key variables between affiliated and non-affiliated analysts. BIAS and $A C C U$ mean (median) values for all firms are $-0.03(-0.01)$ and 0.04 (0.02), indicating that analysts provide optimistic but inaccurate forecasts in general (Fried \& Givoly, 1982; Klein, 1990; Francis \& Philbrick, 1993; Das et al. 1998). Further, BIAS and $A C C U$ mean (median) value for firms intending to issue bonds are $-0.04(-0.01)$ and $0.06(0.02)$, suggesting that analysts provide more optimistic but less accurate forecasts for firms intending to issue bonds than other firms.

The mean (median) differences in $B I A S$ and $A C C U$ between firms intending to issue bonds and other firms, and affiliated and non-affiliated analysts are all statistically significant at the $1 \%$ level, but the median difference in $B I A S$ between firms intending to issue bonds and other firms. However, most of the control variables are also significantly different between firms intending to issue bonds and other firms, and between affiliated and non-affiliated analysts. This reveals a possibility that the differences in the properties of analysts' forecasts may not be caused by our variables of interest, i.e., bond issuance and affiliation of analysts' analysts with underwriters. We examine this issue in multiple regressions later. 
Table 2. Descriptive Statistics

\begin{tabular}{l|c|c|c|c|c|c|c|c|c|}
\hline \multicolumn{2}{c}{\begin{tabular}{c} 
Panel A. Descriptive Statistics of Key Variables \\
\multicolumn{1}{c}{ Variables }
\end{tabular}} & Observations & Mean & $\mathbf{1 \%}$ & $\begin{array}{c}\mathbf{1}^{\text {st }} \\
\text { Quantile }\end{array}$ & Median & $\begin{array}{c}\mathbf{3}^{\text {rd }} \\
\text { Quantile }\end{array}$ & $\begin{array}{c}\text { 99\% } \\
\text { Standard } \\
\text { Deviation }\end{array}$ \\
\hline BIAS & 13,588 & -0.04 & -0.73 & -0.04 & -0.01 & 0.01 & 0.12 & 0.12 \\
\hline ACCU & 13,588 & 0.06 & 0.00 & 0.01 & 0.02 & 0.05 & 0.73 & 0.11 \\
\hline UNWRT & 13,588 & 0.08 & 0.00 & 0.00 & 0.00 & 0.00 & 1.00 & 0.27 \\
\hline MAGNI & 13,588 & 0.05 & 0.00 & 0.01 & 0.02 & 0.06 & 0.38 & 0.06 \\
\hline SIZE (bill won) & 13,588 & 8,402 & 129 & 2,136 & 5,317 & 13,376 & 29,587 & 7,809 \\
\hline LEV & 13,588 & 0.51 & 0.19 & 0.40 & 0.53 & 0.61 & 0.80 & 0.14 \\
\hline VOL & 13,588 & 0.18 & 0.10 & 0.14 & 0.18 & 0.22 & 0.34 & 0.06 \\
\hline BM & 13,588 & 0.69 & 0.09 & 0.38 & 0.58 & 0.93 & 2.43 & 0.44 \\
\hline ROE & 13,588 & 0.05 & -1.64 & 0.02 & 0.06 & 0.16 & 0.38 & 0.28 \\
\hline DGAP(days) & 13,588 & 260 & 117 & 210 & 267 & 320 & 364 & 69 \\
\hline
\end{tabular}

Panel B. Mean (Median) Difference of Key Variables

\begin{tabular}{|c|c|c|c|c|c|c|}
\hline \multirow[b]{2}{*}{ Variables } & \multicolumn{3}{|c|}{ Mean Difference } & \multicolumn{3}{|c|}{ Median Difference } \\
\hline & $\begin{array}{c}\text { UNWRT }=0[\mathrm{~A}] \\
(\mathrm{N}=12,496)\end{array}$ & $\begin{array}{c}\text { UNWRT }=1[\mathrm{~B}] \\
(\mathrm{N}=1,092)\end{array}$ & $\begin{array}{c}\text { Mean-Diff } \\
\mathbf{t}([\mathrm{A}]-[\mathrm{B}])\end{array}$ & $\begin{array}{c}\text { UNWRT }=0[\mathrm{~A}] \\
(\mathrm{N}=12,496)\end{array}$ & $\begin{array}{c}\text { UNWRT }=1[B] \\
(N=1,092)\end{array}$ & $\begin{array}{c}\text { Median-Diff } \\
\mathbf{z}([\mathrm{A}]-[\mathrm{B}])\end{array}$ \\
\hline BIAS & -0.03 & -0.07 & $0.04^{* * *}$ & -0.01 & -0.02 & $0.01^{* * *}$ \\
\hline $\mathrm{ACCU}$ & 0.05 & 0.09 & $-0.04^{* * *}$ & 0.02 & 0.03 & $-0.01^{* * *}$ \\
\hline MAGNI & 0.05 & 0.06 & $-0.01^{* * *}$ & 0.02 & 0.04 & $-0.02^{* * *}$ \\
\hline SIZE (bill won) & 8,528 & 6,957 & $1,571^{* * *}$ & 5,625 & 4,239 & $1,386^{* * *}$ \\
\hline LEV & 0.51 & 0.54 & $-0.03^{* * *}$ & 0.52 & 0.54 & $-0.02^{* * *}$ \\
\hline VOL & 0.18 & 0.19 & $-0.01^{* * *}$ & 0.18 & 0.19 & $-0.01^{* * *}$ \\
\hline $\mathrm{BM}$ & 0.69 & 0.62 & $0.07^{* * *}$ & 0.60 & 0.53 & $0.07^{* * *}$ \\
\hline ROE & 0.05 & 0.04 & 0.01 & 0.06 & 0.06 & -0.00 \\
\hline DGAP(days) & 260 & 262 & -2.00 & 266 & 270 & -4.00 \\
\hline
\end{tabular}

***,**,* indicate statistical significance at the $1 \%, 5 \%$, and $10 \%$ levels (two-tailed) or better, respectively.

\subsection{Correlation}

As a preliminary check on whether underwriting relationship affects affiliated analysts' forecast properties, we calculate correlations among key variables used in our analyses. We report Pearson/Spearman correlation coefficients in the upper/under diagonal in Table 3. Consistent with our predictions, the correlation between BIAS (ACCU) and UNWRT is -0.074 (0.079) and significant at the $1 \%$ level, suggesting affiliated analysts issue more optimistic but less accurate forecasts. As expected, the correlation between BIAS (ACCU) and MAGNI is positive (negative): the coefficient estimates on MAGNI for BIAS (ACCU) are -0.387 and 0.395 and are significant at the $1 \%$ level. Spearman correlation coefficients are generally similar to Pearson correlation. We also calculate the variance inflation factor (VIF) values among the key variables to check the multicollinearity problem, but find that none of the VIF values exceed 2.57 in any of the regressions, demonstrating an absence of any significant multicollinearity issue in the subsequent multivariate regressions. 
Table 3. Correlation Matrix (p-values in parenthesis)

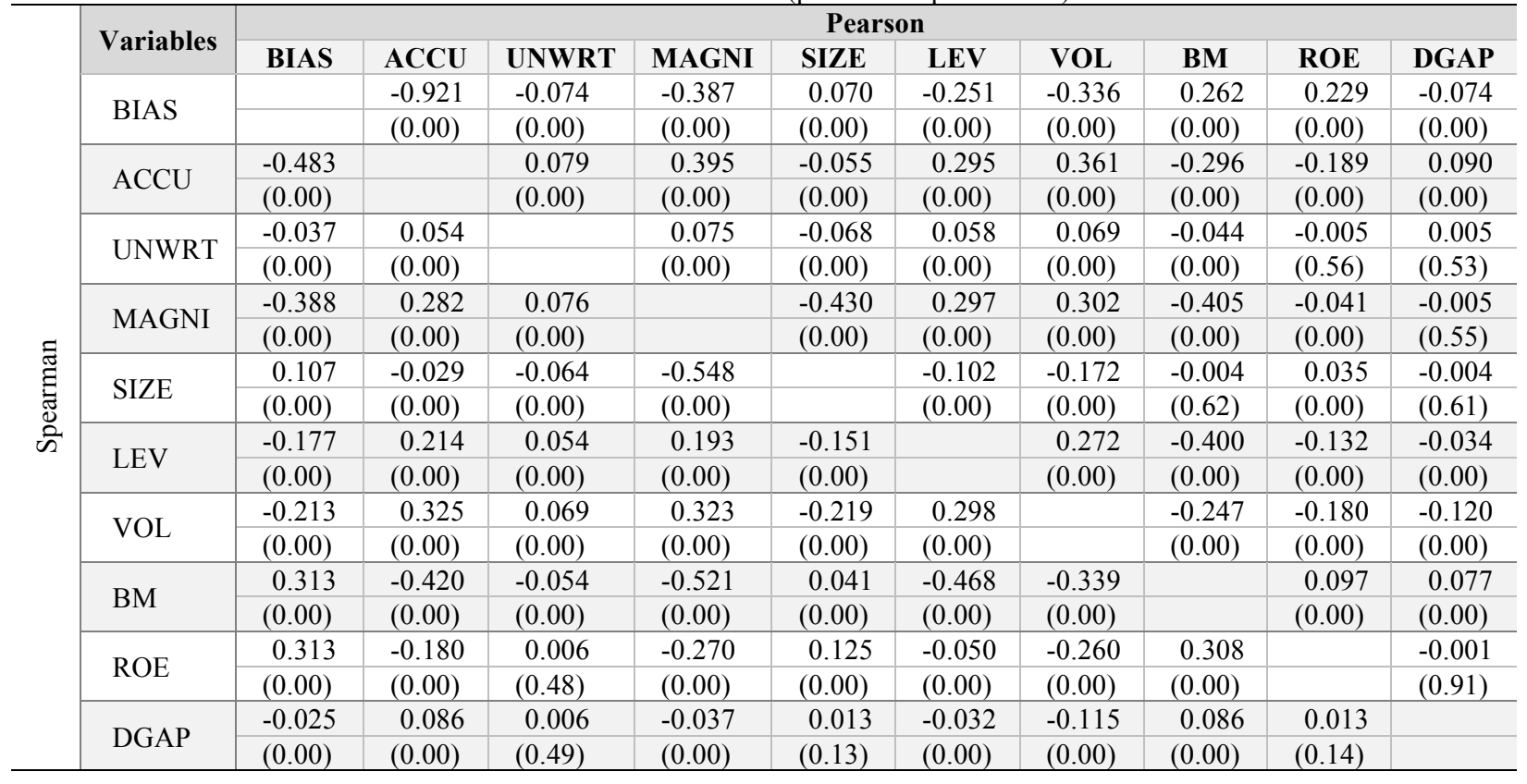

\section{EMPIRICAL RESULTS}

\subsection{Difference in the Properties of Analysts' Forecasts for Firms Intending to Issue Bonds Between Affiliated and Non-Affiliated Analysts}

Hypotheses 1 through 3 compare the properties of analysts' forecasts for firms intending to issue bonds between affiliated and non-affiliated analysts. Therefore, we only use analysts' forecasts for firms intending to issue bonds in the analysis.

First, we univariately compare whether the difference in the properties of analysts' forecasts between affiliated and non-affiliated analysts differs depending on the forecast horizon and the amount of bonds to be issued. Table 4 shows the overall difference in analysts forecast according to the affiliation. More specifically, Panels A and B of Table 5 show the results of overall difference in analysts forecast over the forecast horizon based on the upper and lower $25 \%$ sub-samples based on the amount of bonds to be issued (MAGNI).

From Table 4, in general, we observe that the amount of newly issued corporate bonds significantly affects analysts' forecasts, and that this effect is stronger for affiliate analysts' forecasts than for those of non-affiliate analysts. More specifically, we find that, 6 months to 5 months before bond issuance, affiliated analysts issue more optimistic and less accurate forecasts for firms intending to issue bonds in the upper $25 \%$ amount. For example, the mean difference of bias $(B I A S)$ between non-affiliated and affiliated analysts' forecasts for firms in the upper $25 \%$ bond issuance is 0.062 , significant at $5 \%$, while the mean difference of bias $(B I A S)$ between non-affiliated and affiliated analysts' forecasts for firms in the lower $25 \%$ bond issuance is only 0.022 and insignificant. The mean difference of the accuracy $(A C C U)$ is also generally similar to the mean difference on the bias $(B I A S)$, i.e., the mean difference of accuracy $(A C C U)$ between non-affiliated and affiliated analysts' forecasts for firms in the upper $25 \%$ bond issuance (-0.057) is significantly smaller than the mean difference of accuracy $(A C C U$ ) between non-affiliated and affiliated analyst's forecasts for firms in the lower $25 \%$ bond issuance $(-0.028)$. These differences decrease as the forecasts approach the bond issuance date. 
Table 4. Univariate Test Results of Forecast Optimism and Accuracy by the Amount of Bonds to be Issued and forecast horizon Panel A. Upper $25 \%$ in the amount of Corporate Bonds to be issued

\begin{tabular}{|c|c|c|c|c|c|c|c|c|c|}
\hline \multirow[b]{2}{*}{ Parameter } & \multirow{2}{*}{$\begin{array}{c}\text { Number of } \\
\text { Months before } \\
\text { Issuance }\end{array}$} & \multicolumn{3}{|c|}{ BIAS } & \multicolumn{3}{|c|}{ ACCU } & \multicolumn{2}{|c|}{ \# of Obs. } \\
\hline & & $\begin{array}{c}\text { UNWRT } \\
=0\end{array}$ & $\begin{array}{c}\text { UNWRT } \\
=1\end{array}$ & Diff. & $\begin{array}{c}\text { UNWRT } \\
=0\end{array}$ & $\begin{array}{c}\text { UNWRT } \\
=1\end{array}$ & Diff. & $\begin{array}{c}\text { UNWRT } \\
=0\end{array}$ & $\begin{array}{c}\text { UNWRT } \\
=1\end{array}$ \\
\hline \multirow{3}{*}{ Mean } & $\begin{array}{l}1 \sim 2 \text { month } \\
\text { before }\end{array}$ & -0.105 & -0.137 & $0.032^{* *}$ & 0.122 & 0.148 & $-0.026^{*}$ & 1,051 & 164 \\
\hline & $\begin{array}{l}3 \sim 4 \text { month } \\
\text { before }\end{array}$ & -0.117 & -0.129 & 0.012 & 0.138 & 0.154 & -0.016 & 867 & 123 \\
\hline & $\begin{array}{l}5 \sim 6 \text { month } \\
\text { before }\end{array}$ & -0.099 & -0.161 & $0.062^{* *}$ & 0.128 & 0.185 & $-0.057^{* *}$ & 617 & 94 \\
\hline \multirow{3}{*}{ Median } & $\begin{array}{l}1 \sim 2 \text { month } \\
\text { before }\end{array}$ & -0.037 & -0.056 & $0.019^{*}$ & 0.042 & 0.066 & -0.024 & 1,051 & 164 \\
\hline & $\begin{array}{l}\text { 3 4 month } \\
\text { before }\end{array}$ & -0.043 & -0.041 & -0.002 & 0.052 & 0.063 & -0.011 & 867 & 123 \\
\hline & $\begin{array}{l}5 \sim 6 \text { month } \\
\text { before }\end{array}$ & -0.034 & -0.035 & 0.001 & 0.053 & 0.057 & -0.004 & 617 & 94 \\
\hline
\end{tabular}

Panel B. Lower 25\% in Magnitude of Newly Issued Corporate Bond

\begin{tabular}{|c|c|c|c|c|c|c|c|c|c|}
\hline \multirow[b]{2}{*}{ Parameter } & \multirow{2}{*}{$\begin{array}{c}\text { Number of } \\
\text { Months before } \\
\text { Issuance }\end{array}$} & \multicolumn{3}{|c|}{ BIAS } & \multicolumn{3}{|c|}{ ACCU } & \multicolumn{2}{|c|}{ \# of Obs. } \\
\hline & & $\begin{array}{c}\text { UNWRT } \\
=0\end{array}$ & $\begin{array}{c}\text { UNWRT } \\
=1\end{array}$ & Diff. & $\begin{array}{c}\text { UNWRT } \\
=0\end{array}$ & $\begin{array}{c}\text { UNWRT } \\
=1\end{array}$ & Diff. & $\begin{array}{c}\text { UNWRT } \\
=0\end{array}$ & $\begin{array}{c}\text { UNWRT } \\
=1\end{array}$ \\
\hline \multirow{3}{*}{ Mean } & $\begin{array}{c}1 \sim 2 \text { month } \\
\text { before }\end{array}$ & -0.001 & 0.001 & -0.002 & 0.023 & 0.023 & 0.000 & 1,120 & 61 \\
\hline & $\begin{array}{l}3 \sim 4 \text { month } \\
\text { before }\end{array}$ & -0.000 & -0.009 & 0.008 & 0.024 & 0.041 & $-0.017^{* * *}$ & 944 & 66 \\
\hline & $\begin{array}{l}5 \sim 6 \text { month } \\
\text { before }\end{array}$ & 0.001 & -0.021 & 0.022 & 0.037 & 0.066 & $-0.029^{* * *}$ & 740 & 45 \\
\hline \multirow{3}{*}{ Median } & $\begin{array}{l}1 \sim 2 \text { month } \\
\text { before }\end{array}$ & 0.002 & 0.012 & -0.010 & 0.015 & 0.019 & -0.004 & 1,120 & 61 \\
\hline & $\begin{array}{l}3 \sim 4 \text { month } \\
\text { before }\end{array}$ & 0.002 & 0.003 & -0.001 & 0.019 & 0.030 & $-0.011^{* * *}$ & 944 & 66 \\
\hline & $\begin{array}{l}5 \sim 6 \text { month } \\
\text { before }\end{array}$ & 0.002 & -0.006 & 0.008 & 0.028 & 0.056 & $-0.028^{* * *}$ & 740 & 45 \\
\hline
\end{tabular}

***,***, indicate statistical significance at the $1 \%, 5 \%$, and $10 \%$ levels (two-tailed) or better, respectively.

To summarize, these findings indicate that affiliated analysts generally issue more optimistic and less accurate forecasts than non-affiliated analysts for firms intending to issue bonds when the forecast horizon is long, i.e., underwriters are more likely yet to be determined. Further, the results also indicate that analysts' forecasts are likely to be more optimistic and less accurate mainly due to the magnitude of COI induced from the bond issuance amount. 
Table 5. Regression Results; Forecast Properties of Analysts in Underwriting House

\begin{tabular}{|c|c|c|c|c|c|}
\hline \multicolumn{6}{|c|}{ Panel A. Forecast Bias } \\
\hline \multicolumn{6}{|c|}{$\begin{array}{l}\text { BIAS }(\text { or } A C C U)=\alpha_{0}+\alpha_{1} U N W R T_{i, t}+\alpha_{2} M A G N I_{i, t}+\alpha_{3} S I Z E_{i, t}+\alpha_{4} L E V_{i, t}+\alpha_{5} V O L_{i, t}+\alpha_{6} B M_{i, t}+\alpha_{7} R O E_{i, t}+\alpha_{8} D A Y G A P_{i, t}+\text { Industry_Fixed } \\
+ \text { Year_Fixed }+\varepsilon\end{array}$} \\
\hline \multirow{2}{*}{$\begin{array}{l}\text { Independent } \\
\text { Variable }\end{array}$} & \multirow{2}{*}{ Sign } & \multicolumn{4}{|c|}{ Dependent Variable $=$ BIAS } \\
\hline & & Estimate & t-value & Estimate & t-value \\
\hline Intercept & $\mathrm{N} / \mathrm{A}$ & $0.256^{* * *}$ & 8.06 & $0.572^{* * *}$ & 17.63 \\
\hline UNWRT & - & $-0.020^{* * *}$ & -6.17 & $-0.017^{* * *}$ & -5.53 \\
\hline$M A G N I$ & - & & & $-0.558^{* * *}$ & -30.54 \\
\hline SIZE & $?$ & -0.000 & -0.34 & $-0.011^{* * *}$ & -13.23 \\
\hline$L E V$ & - & $-0.210^{* * *}$ & -24.26 & $-0.189^{* * *}$ & -22.40 \\
\hline$V O L$ & - & $-0.282^{* * *}$ & -11.32 & $-0.204^{* * *}$ & -8.40 \\
\hline$B M$ & + & $0.026^{* * *}$ & 9.90 & -0.004 & -1.53 \\
\hline$R O E$ & + & $0.093^{* * *}$ & 24.56 & $0.090^{* * *}$ & 24.39 \\
\hline$D G A P$ & - & $-0.050^{* * *}$ & -16.75 & -0.044 & -15.33 \\
\hline \multicolumn{2}{|l|}{ Adj. $\mathrm{R}^{2}$} & \multicolumn{2}{|c|}{$26.50 \%$} & \multicolumn{2}{|c|}{$31.22 \%$} \\
\hline \multicolumn{2}{|l|}{ F-Value } & \multicolumn{2}{|c|}{$234.26^{* * *}$} & \multicolumn{2}{|c|}{$281.35^{* * *}$} \\
\hline \multicolumn{2}{|l|}{ \# Of Samples } & \multicolumn{2}{|c|}{13,588} & \multicolumn{2}{|c|}{13,588} \\
\hline \multicolumn{2}{|l|}{ Market \& Industry } & \multicolumn{2}{|c|}{ fixed } & \multicolumn{2}{|c|}{ fixed } \\
\hline \multicolumn{2}{|l|}{ Max VIF } & \multicolumn{2}{|c|}{2.54} & \multicolumn{2}{|c|}{2.57} \\
\hline
\end{tabular}

Panel B. Forecast Accuracy

\begin{tabular}{|c|c|c|c|c|c|}
\hline \multirow{2}{*}{$\begin{array}{c}\text { Independent } \\
\text { Variable }\end{array}$} & \multirow{2}{*}{ Sign } & \multicolumn{4}{|c|}{ Dependent Variable $=\mathbf{A C C U}$} \\
\hline & & Estimate & t-value & Estimate & t-value \\
\hline Intercept & $\mathrm{N} / \mathrm{A}$ & $-0.455^{* * *}$ & -15.41 & $-0.758^{* * *}$ & -25.23 \\
\hline UNWRT & + & 0.020 & 6.90 & $0.018^{* * *}$ & 6.27 \\
\hline$M A G N I$ & + & & & $0.536^{* * *}$ & 31.67 \\
\hline SIZE & $?$ & $0.004^{* * *}$ & 4.50 & $0.013^{* * *}$ & 17.61 \\
\hline$L E V$ & + & $0.215^{* * *}$ & 26.73 & $0.194^{* * *}$ & 24.93 \\
\hline$V O L$ & + & $0.534^{* * *}$ & 23.13 & $0.459^{* * *}$ & 20.49 \\
\hline$B M$ & - & $-0.022^{* * *}$ & -9.47 & $0.006^{* *}$ & 2.34 \\
\hline$R O E$ & - & $-0.072^{* * *}$ & -20.58 & $-0.069^{* * *}$ & -20.29 \\
\hline$D G A P$ & + & $0.056^{* * *}$ & 20.38 & $0.051^{* * *}$ & 19.06 \\
\hline \multicolumn{2}{|l|}{ Adj. $\mathrm{R}^{2}$} & \multicolumn{2}{|c|}{$29.17 \%$} & \multicolumn{2}{|c|}{$34.04 \%$} \\
\hline \multicolumn{2}{|l|}{ F-Value } & \multicolumn{2}{|c|}{$267.40^{* * *}$} & \multicolumn{2}{|c|}{$319.71^{* * *}$} \\
\hline \multicolumn{2}{|l|}{ \# Of Samples } & \multicolumn{2}{|c|}{13,588} & \multicolumn{2}{|c|}{13,588} \\
\hline \multicolumn{2}{|l|}{ Market \& Industry } & \multicolumn{2}{|c|}{ fixed } & \multicolumn{2}{|c|}{ fixed } \\
\hline \multicolumn{2}{|l|}{ Max VIF } & \multicolumn{2}{|c|}{2.54} & \multicolumn{2}{|c|}{2.57} \\
\hline
\end{tabular}

***,*** indicate statistical significance at the $1 \%, 5 \%$, and $10 \%$ levels (two-tailed) or better, respectively.

Because most control variables are significantly different between affiliated analysts and non-affiliated analysts, we run multivariate regressions using model (1) to test hypotheses 1 to 2 . Table 6 reports the regression results of equation (1) using analysts' forecasts for firms intending to issue bonds. In general, the results are consistent with the predictions of our hypotheses 1 and 2. First, the coefficients on affiliation dummy variable (UNWRT) for optimism and accuracy (BIAS and $A C C U$ ) are -0.020 (0.020) for equation (1), which are significant at the $1 \%$ level. This result implies that potential underwriting relationship in bond issuance induces ex post affiliated analysts to issue more optimistic and less accurate forecasts than ex post non-affiliated analysts. In addition, the coefficients on the amount of bond issuance (MAGNI) for optimism and accuracy ( $B I A S$ and $A C C U$ ) are $-0.558(0.536)$, which are also significant at the $1 \%$ level. This indicates that analysts' forecasting behavior is significantly affected by the amount of newly issued corporate bond in a more optimistic and less accurate way, which is consistent with our third hypothesis.

We estimate equation (2) to test hypothesis 3 by adding the variable which measures the intervening effect of bond issuing amount on underwriting relationship. The results are reported in Table 6 . Table 6 shows that the amount of bond issuance strengthens affiliated analysts' optimistic and inaccurate forecasts, i.e., the coefficients on $U N W R T \times M A G N I$ for $B I A S(A C C U)$ are $-0.386(0.397)$. This finding suggests that the amount of corporate bond to be issued increases the COI which analysts face and thus more strongly affects affiliated analysts' forecasting behavior. 
The ex post underwriting relation also forces analysts' forecasts to be more optimistic and less accurate, as in the estimation of equation (2). The amount of bond to be issued also generally affects ex post non-affiliated analysts' forecasts optimistically and inaccurately.

Control variables generally show signs that are consistent with our predictions. The coefficient estimates on SIZE for optimism and accuracy ( $B I A S$ and $A C C U$ ) are significantly negative (positive) at the $1 \%$ level, indicating that analysts issue less biased and more accurate forecasts due to more information available for firms ( $\mathrm{Gu} \& \mathrm{Wu} 2003)$. The coefficients on $L E V$ and return $V O L$ for BIAS and accuracy (BIAS and $A C C U$ ) are also negative and positive at the $1 \%$ level, respectively, indicating that future earnings for firms that are highly leveraged or volatile in return are less predictable (Lee \& Jeong, 1993; Jeong, 2003; Ahn et al., 2006; Han et al., 2005). Finally, the signs in coefficient estimates on ROE and DAYGAP are also consistent with our expectation.

Table 6. Regression Results; Incremental Effects of Forecast Properties of Analysts in Underwriting House

\begin{tabular}{|c|c|c|c|c|c|c|}
\hline \multicolumn{7}{|c|}{$\begin{array}{l}\text { BIAS }(\text { or ACCU })=\beta_{0}+\beta_{1} U N W R T_{i, t}+\beta_{2} M A G N I_{i, t}+\beta_{3}(U N W R T \times M A G N I)_{i, t}+\beta_{4} S I Z E_{i, t}+\beta_{5} L E V_{i, t}+\beta_{6} V O L_{i, t}+\beta_{7} B M_{i, t}+\beta_{8} R O E_{i, t}+\beta_{9} D A Y G A P_{i,} \\
+ \text { Industry_Fixed }+ \text { Year_Fixed }+v\end{array}$} \\
\hline \multirow{2}{*}{$\begin{array}{c}\text { Independent } \\
\text { Variable }\end{array}$} & \multicolumn{2}{|c|}{ Sign } & \multicolumn{2}{|c|}{ Dependent Variable $=$ BIAS } & \multicolumn{2}{|c|}{$\begin{array}{l}\text { Dependent Variable }= \\
\text { ACCURACY }\end{array}$} \\
\hline & BIAS & ACCURACY & Estimate & t-value & Estimate & t-value \\
\hline Intercept & N/A & $\mathrm{N} / \mathrm{A}$ & $0.567^{* * *}$ & 17.51 & $-0.753^{* * *}$ & -25.13 \\
\hline UNWRT & - & + & $-0.012^{* * *}$ & -3.89 & $0.013^{* * *}$ & 4.46 \\
\hline$M A G N I$ & - & + & $-0.543^{* * *}$ & -29.68 & $0.521^{* * *}$ & 30.75 \\
\hline$U N W R T \times M A G N I$ & - & + & $-0.386^{* * *}$ & -9.21 & $0.397^{* * *}$ & 10.23 \\
\hline SIZE & $?$ & $?$ & $-0.011^{* * *}$ & -13.10 & $0.013^{* * *}$ & 17.49 \\
\hline$L E V$ & - & + & $-0.184^{* * *}$ & -21.89 & $0.189^{* * *}$ & 24.37 \\
\hline$V O L$ & - & + & $-0.209^{* * *}$ & -8.67 & $0.465^{* * *}$ & 20.83 \\
\hline$B M$ & + & - & -0.004 & -1.55 & $0.006^{* *}$ & 2.36 \\
\hline$R O E$ & + & - & $0.090^{* * *}$ & 24.67 & $-0.070^{* * *}$ & -20.59 \\
\hline$D G A P$ & - & + & $-0.044^{* * *}$ & -15.41 & $0.051^{* * *}$ & 19.17 \\
\hline \multicolumn{3}{|l|}{ Adj. $R^{2}$} & \multicolumn{2}{|c|}{-} & \multicolumn{2}{|c|}{$34.54 \%$} \\
\hline \multicolumn{3}{|l|}{ F-Value } & \multicolumn{2}{|c|}{$274.47^{* * *}$} & \multicolumn{2}{|c|}{$312.70^{* * *}$} \\
\hline \multicolumn{3}{|l|}{ \# Of Samples } & \multicolumn{2}{|c|}{13,588} & \multicolumn{2}{|c|}{13,588} \\
\hline \multicolumn{3}{|l|}{ Market \& Industry } & \multicolumn{2}{|c|}{ fixed } & \multicolumn{2}{|c|}{ fixed } \\
\hline \multicolumn{3}{|l|}{ Max VIF } & \multicolumn{2}{|c|}{2.57} & \multicolumn{2}{|c|}{2.57} \\
\hline
\end{tabular}

***,**** indicate statistical significance at the $1 \%, 5 \%$, and $10 \%$ levels (two-tailed) or better, respectively.

\subsection{Possibility of Awarding Underwriting Contract According to The Properties of Analysts' Forecasts}

To test hypothesis 4 , we run logit regression for equation (3) and present the results in Table 7. We expect the coefficients on $B I A S$ and $A C C U$ to be significantly negative and positive, respectively, because we expect that the more analysts forecast optimistically and less accurately, the more likely security companies will secure underwriting contracts. The coefficients on $B I A S$ and $A C C U$ are significantly negative (-1.719) and positive (1.997) at the $1 \%$ level, respectively, which is consistent with our expectation. The marginal effects on BIAS and $A C C U$ are -0.128 and 0.153 , respectively, indicating that $1 \%$ increase in $B I A S(A C C U)$ results in $-0.128 \%(0.153 \%)$ decrease (increase) in the probability of awarding underwriting contract. That is, the more optimistically and less accurately analysts issue forecasts for firms intending to issue bonds, the more likely security companies that hire those analysts can secure underwriting contracts. The market share of underwriting (HOUSE_MS) and size of underwriting companies(HOUSE_AST) are also positively related with underwriting contracts, suggesting that security companies that have a large market share of underwriting contracts and asset size have significantly higher chances of securing underwriting contracts in the bond market. In general, these results are consistent with prior studies. 
Table 7. Results of Logit Regression; Likelihood of Bond Underwriting Contracts to Security Firms

\begin{tabular}{|c|c|c|c|c|c|c|c|c|}
\hline \multicolumn{9}{|c|}{ UNWRT (1 or 0) $=\beta_{0}+\beta_{1}$ Bias(Accuracy) $)_{i, t}+\beta_{2}$ HOUSE_MS $S_{i, t}+\beta_{3} S A M E_{-} H S_{i, t}+\beta_{4} H O U S E_{-}$AST $T_{i, t}+$ Industry_Fixed + Year_Fixed $+v$} \\
\hline \multirow{2}{*}{$\begin{array}{c}\text { Independent } \\
\text { Variable }\end{array}$} & \multicolumn{2}{|c|}{ Sign } & \multicolumn{6}{|c|}{ Dependent Variable $=\overline{U N W R T}$} \\
\hline & BIAS & $\mathbf{A C C U}$ & Estimate & $\begin{array}{c}\text { Wald } \\
\text { Chi-square }\end{array}$ & $\begin{array}{c}\text { Marginal } \\
\text { Effect }\end{array}$ & Estimate & $\begin{array}{c}\text { Wald } \\
\text { Chi-square }\end{array}$ & $\begin{array}{c}\text { Marginal } \\
\text { Effect }\end{array}$ \\
\hline Intercept & N/A & N/A & $-7.919^{* * *}$ & 39.53 & & $-7.818^{* * *}$ & 38.50 & \\
\hline$B I A S(A C C U)$ & - & + & $-1.719^{* * *}$ & 56.31 & -0.128 & $1.997^{* * *}$ & 73.17 & 0.153 \\
\hline HOUSE_MS & \multicolumn{2}{|c|}{+} & $0.245^{* * *}$ & 12.89 & 0.017 & $0.251^{* * *}$ & 13.30 & 0.018 \\
\hline$S A M E \_\bar{H} S T$ & \multicolumn{2}{|c|}{+} & 0.032 & 0.06 & 0.0003 & 0.078 & 0.37 & 0.004 \\
\hline HOUST_AST & \multicolumn{2}{|c|}{+} & $0.196^{* * *}$ & 28.34 & 0.015 & $0.189^{* * *}$ & 26.08 & 0.014 \\
\hline \multicolumn{3}{|l|}{ Pseudo $\overline{\mathrm{R}}^{2}$} & \multicolumn{3}{|c|}{$3.26 \%$} & \multicolumn{3}{|c|}{$3.50 \%$} \\
\hline \multicolumn{3}{|l|}{ Likelihood Ratio $\left(\chi^{2}\right)$} & \multicolumn{3}{|c|}{$191.10^{* * *}$} & \multicolumn{3}{|c|}{$205.16^{* * *}$} \\
\hline \multicolumn{3}{|l|}{ \# Of Samples } & \multicolumn{3}{|c|}{13,588} & \multicolumn{3}{|c|}{13,588} \\
\hline \multicolumn{3}{|l|}{ Market \& Industry } & \multicolumn{3}{|c|}{ fixed } & \multicolumn{3}{|c|}{ fixed } \\
\hline
\end{tabular}

***,*** indicate statistical significance at the $1 \%, 5 \%$, and $10 \%$ levels (two-tailed) or better, respectively.

\section{FURTHER ANALYSIS}

We perform several additional analyses to check the robustness of the results documented in the previous sections. First, we re-estimate equations (1) (3) by using a sub-sample from 6 to 3 months before bond issuance to check how the forecast horizon before bond issuance affects the analysts' forecasts. If the incentive to gain economic benefits as an underwriter forces analysts to issue more optimistic forecasts, affiliated analysts' forecasts will be more biased and less accurate before underwriting contracts are made. We use forecasts made before 6 to 3 months before bond issuance in the estimation, because it usually takes about a quarter to gain underwriting contracts. Therefore, we assume forecasts 6 to 3 months prior to bond issuance are made before bond issuance. This restriction reduces the sample size to 4,784 forecasts and the estimation results are reported in Table 8.

The coefficients on affiliation with underwriters (UNWRT) and the amount of bond issuance (MAGNI) and the interaction of both variables ( $U N W R T \times M A G N I)$ are significantly negative (positive) at the $1 \%$ level for $B I A S(A C C U)$. This is consistent with the result in the previous section. That is, ex post affiliated analysts are more likely to make more optimistic and less accurate forecasts than non-affiliated analysts before underwriting contracts, all analysts issue more optimistic and less accurate forecasts when the expected magnitude of economic benefits is large, and affiliated analysts are affected more by the magnitude of economic benefits.

Second, we re-estimate equation (4) and present the results in Panel C of Table 8 by using a sub-sample from 6 to 3 months before bond issuance to check how the forecast horizon before bond issuance affects the likelihood of awarding bond underwriting contract (UNWRT). As presented, the coefficients on $B I A S$ and $A C C U$ are significantly negative (1.636) and positive (1.980) at the $1 \%$ level, respectively, which is consistent with the results in Table 7 . Also, the marginal effects on $B I A S$ and $A C C U$ are -0.113 and 0.014 , respectively. In addition, consistent with the results in Table 7, the size of underwriting companies (HOUSE_AST) is still positively related with underwriting contracts at the $1 \%$ level (0.220 and 0.209 , respectively) and their marginal effects on (BIAS and $A C C U)$ are 0.015 and 0.014 , respectively. 
Table 8. Regression Results Forecast Properties of Analysts before Underwriting Contract

\begin{tabular}{|c|c|c|c|c|c|}
\hline \multicolumn{6}{|c|}{$\begin{array}{l}\text { Panel A. Forecast Bias } \\
B I A S(\text { or } A C C U)=\beta_{0}+\beta_{1} U N W R T_{i, t}+\beta_{2} M A G N I_{i, t}+\beta \\
+\beta_{9} D A Y G A P_{i, t}+\text { Industry_Fixed }+ \text { Year_Fixed }+v\end{array}$} \\
\hline \multirow{2}{*}{ Independent Variable } & \multirow{2}{*}{ Sign } & \multicolumn{4}{|c|}{ Dependent Variable $=$ BIAS } \\
\hline & & Estimate & t-value & Estimate & t-value \\
\hline Intercept & $\mathrm{N} / \mathrm{A}$ & $1.178^{* * *}$ & 15.85 & $1.161^{* * *}$ & 15.69 \\
\hline$U N W R T$ & - & $-0.021^{* * *}$ & -3.81 & $-0.014^{* * *}$ & -2.41 \\
\hline$M A G N I$ & - & $-0.448^{* * *}$ & -13.39 & $-0.432^{* * *}$ & -12.96 \\
\hline$U N W R T \times M A G N I$ & - & & & $-0.545^{* * *}$ & -7.05 \\
\hline SIZE & $?$ & $-0.010^{* * *}$ & -6.57 & $-0.009^{* * *}$ & -6.42 \\
\hline$L E V$ & - & $-0.250^{* * *}$ & -16.73 & $-0.243^{* * *}$ & -16.32 \\
\hline$V O L$ & - & $-0.240^{* * *}$ & -5.32 & $-0.242^{* * *}$ & -5.39 \\
\hline$B M$ & + & -0.004 & -0.76 & -0.004 & -0.88 \\
\hline$R O E$ & + & $0.116^{* * *}$ & 16.27 & $0.117^{* * *}$ & 16.44 \\
\hline$D G A P$ & - & $-0.141^{* * *}$ & -14.26 & $-0.141^{* * *}$ & -14.27 \\
\hline \multicolumn{2}{|l|}{ Adj. $R^{2}$} & \multicolumn{2}{|c|}{$34.51 \%$} & \multicolumn{2}{|c|}{$35.17 \%$} \\
\hline \multicolumn{2}{|l|}{ F-Value } & \multicolumn{2}{|c|}{$121.01^{* * *}$} & \multicolumn{2}{|c|}{$118.95^{* * *}$} \\
\hline \multicolumn{2}{|l|}{ \# Of Samples } & \multicolumn{2}{|c|}{4,784} & \multicolumn{2}{|c|}{4,784} \\
\hline \multicolumn{2}{|l|}{ Market \& Industry } & \multicolumn{2}{|c|}{ fixed } & \multicolumn{2}{|c|}{ fixed } \\
\hline \multicolumn{2}{|l|}{ Max VIF } & \multicolumn{2}{|c|}{2.72} & \multicolumn{2}{|c|}{2.72} \\
\hline
\end{tabular}

Panel B. Forecast Accuracy

\begin{tabular}{|c|c|c|c|c|c|}
\hline \multirow{2}{*}{ Independent Variable } & \multirow{2}{*}{ Sign } & \multicolumn{4}{|c|}{ Dependent Variable $=$ ACCURACY } \\
\hline & & Estimate & t-value & Estimate & t-value \\
\hline Intercept & $\mathrm{N} / \mathrm{A}$ & $-1.202^{* * *}$ & -17.27 & $-1.183^{* * *}$ & -17.11 \\
\hline$U N W R T$ & + & $0.025^{* * *}$ & 4.83 & $0.017^{* * *}$ & 3.18 \\
\hline$M A G N I$ & + & $0.437^{* * *}$ & 13.97 & $0.420^{* * *}$ & 13.48 \\
\hline$U N W R T \times M A G N I$ & + & & & $0.598^{* * *}$ & 8.27 \\
\hline$S I Z E$ & $?$ & $0.012^{* * *}$ & 8.65 & $0.012^{* * *}$ & 8.49 \\
\hline$L E V$ & + & $0.260^{* * *}$ & 18.57 & $0.253^{* * *}$ & 18.13 \\
\hline$V O L$ & + & $0.444^{* * *}$ & 10.50 & $0.446^{* * *}$ & 10.63 \\
\hline$B M$ & - & 0.005 & 1.05 & 0.005 & 1.20 \\
\hline$R O E$ & - & $-0.095^{* * *}$ & -14.23 & $-0.096^{* * *}$ & -14.43 \\
\hline$D G A P$ & + & $0.127^{* * *}$ & 13.67 & $0.126^{* * *}$ & 13.69 \\
\hline \multicolumn{2}{|l|}{ Adj. $R^{2}$} & \multicolumn{2}{|c|}{$35.66 \%$} & \multicolumn{2}{|c|}{$36.56 \%$} \\
\hline \multicolumn{2}{|l|}{ F-Value } & \multicolumn{2}{|c|}{$127.24^{* * *}$} & \multicolumn{2}{|c|}{$126.28^{* * *}$} \\
\hline \multicolumn{2}{|l|}{ \# Of Samples } & \multicolumn{2}{|c|}{4,784} & \multicolumn{2}{|c|}{4,784} \\
\hline \multicolumn{2}{|l|}{ Market \& Industry } & \multicolumn{2}{|c|}{ fixed } & \multicolumn{2}{|c|}{ fixed } \\
\hline \multicolumn{2}{|l|}{ Max VIF } & \multicolumn{2}{|c|}{2.72} & \multicolumn{2}{|c|}{2.72} \\
\hline
\end{tabular}

Panel C. Logit Analysis Results

UNWRT (1 or 0) $=\beta_{0}+\beta_{1}$ Bias (Accuracy) $)_{i, t}+\beta_{2}$ HOUSE_MS $S_{i, t}+\beta_{3} S A M E_{-} H S_{i, t}+\beta_{4} H O U S E_{-}$AST $T_{i, t}+$ Industry_Fixed + Year_Fixed $+v$

\begin{tabular}{|c|c|c|c|c|c|c|c|c|}
\hline \multirow{2}{*}{$\begin{array}{c}\text { Independent } \\
\text { Variable }\end{array}$} & \multicolumn{2}{|c|}{ Sign } & \multicolumn{6}{|c|}{ Dependent Variable $=U N W R T$} \\
\hline & BIAS & $\mathbf{A C C U}$ & Estimate & $\begin{array}{c}\text { Wald Chi- } \\
\text { square }\end{array}$ & $\begin{array}{c}\text { Marginal } \\
\text { Effect }\end{array}$ & Estimate & $\begin{array}{l}\text { Wald Chi- } \\
\text { square }\end{array}$ & $\begin{array}{c}\text { Marginal } \\
\text { Effect }\end{array}$ \\
\hline Intercept & N/A & $\mathrm{N} / \mathrm{A}$ & $-6.921^{* * *}$ & 24.21 & & $-6.793^{* * *}$ & 23.18 & \\
\hline$B I A S(A C C U)$ & - & + & $-1.636^{* * *}$ & 19.74 & -0.113 & 1.980 & 28.35 & 0.014 \\
\hline HOUSE_MS & \multicolumn{2}{|c|}{+} & 0.137 & 1.29 & 0.010 & 0.139 & 1.32 & 0.010 \\
\hline$S A M E \_H S T$ & \multicolumn{2}{|c|}{+} & 0.001 & 0.001 & -0.002 & 0.071 & 0.11 & 0.003 \\
\hline HOUST_AST & \multicolumn{2}{|c|}{+} & $0.220^{* * *}$ & 11.26 & 0.015 & $0.209^{* * *}$ & 10.11 & 0.014 \\
\hline \multicolumn{3}{|c|}{ Pseudo $\mathrm{R}^{2}$} & \multicolumn{3}{|c|}{$2.84 \%$} & \multicolumn{3}{|c|}{$3.21 \%$} \\
\hline \multicolumn{3}{|c|}{ Likelihood Ratio $\left(\chi^{2}\right)$} & \multicolumn{3}{|c|}{$56.59^{* * *}$} & \multicolumn{3}{|c|}{$63.98^{* * *}$} \\
\hline \multicolumn{3}{|c|}{ \# Of Samples } & \multicolumn{3}{|c|}{4,784} & \multicolumn{3}{|c|}{4,784} \\
\hline \multicolumn{3}{|l|}{ Market \& Industry } & \multicolumn{3}{|c|}{ fixed } & \multicolumn{3}{|c|}{ fixed } \\
\hline
\end{tabular}

***,**** indicate statistical significance at the $1 \%, 5 \%$, and $10 \%$ levels (two-tailed) or better, respectively. 
As a second robustness check, we employ a least absolute deviated (LAD) ${ }^{3}$ estimation methodology and run regressions (1) (2). Gu and $\mathrm{Wu}(2003)$ argue that part of the observed analyst BIAS can be a result of analysts' efforts to improve $A C C U$ when the earnings distribution is skewed. Therefore, following the prior literature, we use LAD estimator to alleviate concerns that analysts' true objective may be the minimization of mean absolute errors (Gu \& Wu 2003; Basu \& Markov 2004).

As reported in the Panel A of Table 9, all variables show the expected significant relations except that the affiliated with underwriter variable (UNWRT) is insignificantly related with $B I A S$, even though it is positive. That is, the amount of bond issuance $(M A G N I)$ and interaction of both variables $(U N W R T \times M A G N I)$ are positively (negatively) related with $B I A S(A C C U)$ at least at the $10 \%$ or lower level. These results are qualitatively similar to those reported in section 5.

As final robustness check, we re-estimated model (2) following methodology suggested by Petersen (2009). Petersen (2009) argues that in the study where panel data sets are used, OLS standard errors may be biased if the residuals are correlated across observation and the residuals are not independent. To control this problem, he shows that using standard errors clustered by firm and/or time is an effective approach to deter the problem. The Panel B of Table 9 provides the results. As presented, adjusted t-values with clustered standard errors of UNWRT, MAGNI and $U N W R T \times M A G N I$ for $B I A S(A C C U)$ are $-2.13(2.23),-1.95(2.02)$ and $-1.69(1.84)$, respectively, which are still statistically significant, indicating that incorporation of clustered standard errors into our models does not significantly change our main findings.

Table 9. Regression Results Estimation of Least Absolute Deviation and clustered standard errors

\begin{tabular}{|c|c|c|c|c|c|c|}
\hline \multicolumn{7}{|c|}{ Panel A. Estimation of Least Absolute Deviation } \\
\hline \multicolumn{7}{|c|}{$\begin{array}{l}\text { BIAS }(\text { or ACCU })=\beta_{0}+\beta_{1} U N W R T_{i, t}+\beta_{2} M A G N I_{i, t}+\beta_{3}(U N W R T \times M A G N I)_{i, t}+\beta_{4} S I Z E_{i, t}+\beta_{5} L E V_{i, t}+\beta_{6} V O L_{i, t}+\beta_{7} B M_{i, t}+\beta_{8} R O E_{i, t}+\beta_{9} D G A P_{i, t} \\
+ \text { Industry_Fixed }+ \text { Year_Fixed }+v\end{array}$} \\
\hline \multirow{2}{*}{$\begin{array}{l}\text { Independent } \\
\text { Variable }\end{array}$} & \multicolumn{2}{|c|}{ Sign } & \multicolumn{2}{|c|}{ Dependent Variable $=$ BIAS } & \multicolumn{2}{|c|}{ Dependent Variable $=$ ACCU } \\
\hline & BIAS & ACCURACY & Estimate & z-value & Estimate & z-value \\
\hline Intercept & $\mathrm{N} / \mathrm{A}$ & N/A & 0.010 & 0.73 & $-0.199^{* * *}$ & -17.84 \\
\hline UNWRT & - & + & 0.002 & 1.60 & $0.002^{*}$ & 1.83 \\
\hline$M A G N I$ & - & + & $-0.264^{* * *}$ & -41.94 & $0.166^{* * *}$ & 33.98 \\
\hline$U N W R T \times M A G N I$ & - & + & $-0.127^{* * *}$ & -9.14 & $0.152^{* * *}$ & 14.13 \\
\hline \multicolumn{3}{|l|}{ Pseudo $\mathrm{R}^{2}$} & \multicolumn{2}{|c|}{$11.58 \%$} & \multicolumn{2}{|c|}{$11.74 \%$} \\
\hline \multicolumn{3}{|l|}{ \# Of Samples } & \multicolumn{2}{|c|}{13,588} & \multicolumn{2}{|c|}{13,588} \\
\hline \multicolumn{3}{|l|}{ Market \& Industry } & \multicolumn{2}{|c|}{ fixed } & \multicolumn{2}{|c|}{ fixed } \\
\hline
\end{tabular}

Panel B. Regression results of clustered standard errors

$B I A S($ or $A C C U)=\beta_{0}+\beta_{1} U N W R T_{i, t}+\beta_{2} M A G N I_{i, t}+\beta_{3}(U N W R T \times M A G N I)_{i, t}+\beta_{4} S I Z E_{i, t}+\beta_{5} L E V_{i, t}+\beta_{6} V O L_{i, t}+\beta_{7} B M_{i, t}+\beta_{8} R O E_{i, t}+\beta_{9} D A Y G A P_{i, t}$

+ Industry_Fixed + Year_Fixed $+v$

\begin{tabular}{|c|c|c|c|c|c|c|}
\hline \multirow{2}{*}{$\begin{array}{c}\text { Independent } \\
\text { Variable }\end{array}$} & \multicolumn{2}{|c|}{ Sign } & \multicolumn{2}{|c|}{ Dependent Variable $=$ BIAS } & \multicolumn{2}{|c|}{ Dependent Variable $=$ ACCU } \\
\hline & BIAS & ACCURACY & Estimate & t-value & Estimate & t-value \\
\hline Intercept & $\mathrm{N} / \mathrm{A}$ & $\mathrm{N} / \mathrm{A}$ & $0.567^{*}$ & 1.80 & $-0.753^{* *}$ & -2.57 \\
\hline$U N W R T$ & - & + & $-0.012^{* *}$ & -2.13 & $0.013^{* *}$ & 2.23 \\
\hline$M A G N I$ & - & + & $-0.543^{*}$ & -1.95 & $0.521^{* *}$ & 2.02 \\
\hline$U N W R T \times M A G N I$ & - & + & $-0.386^{*}$ & -1.69 & $0.397^{*}$ & 1.84 \\
\hline SIZE & $?$ & $?$ & -0.011 & -1.37 & $0.013^{*}$ & 1.81 \\
\hline$L E V$ & - & + & $-0.184^{* *}$ & -2.50 & $0.189^{* * *}$ & 2.64 \\
\hline$V O L$ & - & + & -0.209 & -0.86 & $0.465^{* *}$ & 2.14 \\
\hline$B M$ & + & - & -0.004 & -0.23 & 0.006 & 0.34 \\
\hline$R O E$ & + & - & $0.090^{*}$ & 1.73 & -0.070 & -1.48 \\
\hline$D G A P$ & - & + & $-0.044^{* * *}$ & -3.13 & $0.051^{* * *}$ & 3.97 \\
\hline \multicolumn{3}{|l|}{ Adj. R2 } & \multicolumn{2}{|c|}{$31.76 \%$} & \multicolumn{2}{|c|}{$34.65 \%$} \\
\hline \multicolumn{3}{|l|}{ F-value } & \multicolumn{2}{|c|}{$15.28^{* * *}$} & \multicolumn{2}{|c|}{$11.16^{* * *}$} \\
\hline \multicolumn{3}{|l|}{ \# of samples } & \multicolumn{2}{|c|}{13,588} & \multicolumn{2}{|c|}{13,588} \\
\hline
\end{tabular}

***,**,* indicates statistical significance at the $1 \%, 5 \%$, and $10 \%$ levels (two-tailed) or better, respectively.

\footnotetext{
${ }^{3}$ We adopt LAD regression methodology for models 1 and 2 because the dependent variable of the model 3 is binary type. 


\section{SUMMARY AND CONCLUSION}

In this paper, we analyze the properties of analyst forecasts in the bond market when analysts face potential COI. When analysts are affiliated with security companies that provide underwriting services, we expect analysts to forecast more optimistically but less accurately for firms intending to issue bonds and these analysts' forecasting behavior to increase the chance of securing underwriting contracts.

During the period 2000 to 2008 , we find that analysts forecast more optimistically but less accurately for firms intending to issue bonds, as expected, and that the amount of bond issuance also affects analysts to forecast more optimistically but less accurately. Furthermore, we find that analysts affiliated with security companies that eventually become underwriters issue more optimistic and less accurate forecasts than analysts affiliated with security companies that eventually do not become underwriters. We further document that security companies with analysts who issue more optimistic but less accurate forecasts are more likely to secure underwriting contracts. We go on to analyze the properties of analysts' forecasts only with forecasts made before the underwriting contracts are determined and obtain qualitatively similar results to those of the full sample analysis. These results are consistent with the notion that analysts are affected by the mere existence of potential COI, and that bond issuing companies are also affected by these analysts' forecasts because it may increase the chance to raise capital more cheaply due to higher valuations.

Our results suggest that investors in the stock market need to discount more earnings forecasts for firms intending to issue bonds, especially made by analysts affiliated with security companies that provide underwriting service, even when forecasts are made before underwriting contracts. However, the following study limitations should be noted. Our results are based only on a short 9-year sample from only one country, which warrants cross country comparison study. Furthermore, our results do not suggest that analyst forecasts in the stock market are less optimistic and more accurate.

\section{AUTHOR BIOGRAPHIES}

Seong Ho Bae is an assistant professor of Kyungpook National University School of Business Administration. E-mail: shobae@knu.ac.kr

Seok Woo Jeong is a professor of Korea University Business School. E-mail: jeong@korea.ac.kr

Woo Jae Lee is a visiting professor of School of Business at the Chungnam National University. E-mail: woojae.lie@gmail.com

Kwangwuk Oh is an associate professor of Korea University College of Global Business.

E-mail: avnini92@korea.ac.kr

\section{REFERENCES}

Ahn, Y. Y., Y. T. Yoo, Y. J. Cho, H. H. Shin \& J. H. Chang (2006). Financial analyst, earnings forecast accuracy, earnings forecast error, analysts-specific characteristics. Korean Accounting Review, 31(4) 1-24.

Basu, S., \& S. Markov (2004). Loss function assumptions in rational expectations tests on financial analysts' earnings forecasts. Journal of Accounting and Economics, 38(December) 171-203.

Bhushan, R. (1989). Firm characteristics and analyst following. Journal of Accounting and Economics, 7(2-3) 255-274.

Chan, L. K. C, J. Karceski, \& J. Lakonishok (2007). Analysts' conflict of interest and biases in earnings forecast. Journal of Financial Quantitative Analysis, 42(4) 893-913.

Cowen, A., B. Groysberg, \& P. Healy (2006). Which types of analyst firms are more optimistic?. Journal of Accounting and Economics, 41(1) 119-146.

Das, S., C. Levine \& K. Sivaramakrishnan (1998). Earnings predictability and bias in analysts' earnings forecasts. The Accounting Review, 73(2) 277-294.

Dechow, P., Hutton, A., \& R. Sloan (2000). The Relation between analysts' forecasts of long-term earnings growth and stock price performance following equity offerings. Contemporary Accounting Research, 17(1) 1-32.

Dugar, A., \& S. Nathan (1995). The effect of investment banking relationship on financial analysts' earnings forecasts and investment recommendations. Contemporary Accounting Research, 12(1) 131-160. 
Duru, A. \& D. M. Reeb (2002). International diversification and analysts' forecast accuracy and bias. The Accounting Review, 77(2) 415-433.

Francis. J. \& D. Philbrick (1993). Analysts' decision as products of multi-task environment. Journal of Accounting Research, 31(2) 216-231.

Francis, J. \& R. Willis (2000). A Multivariate Test of Incentive, Selection and Judgmental Explanations for Analyst Bias. Working paper, Duke University.

Fried, D., \& D. Givoly (1982). Financial analysts' forecasts of earnings: A better surrogate for market expectations. Journal of Accounting and Economics, 4(2) 85-107.

Grinblatt, M. \& S. Titman (1998). Financial Markets and Corporate Strategy. McGraw-Hill

Gu, Z. \& J. S. Wu (2003). Earnings skewness and analysts' forecast bias. Journal of Accounting and Economics 35(1) 5-29.

Han, S., S. L. Joo, \& W. J. Kim (2005). Investor sophistication and patterns in analysts' earnings forecasts. Journal of Korean Securities Association, 34(1) 195-226.

Healy, P. M., \&, J. M. Wahlen. (1999). A review of the earnings management literature and its implications for standard setting. Accounting Horizons, 13(4) 365-383.

Hodgkinson, Lynn (2001). analysts' forecasts and the broker relationship. Journal of Business Finance \& Accounting, 28(7-8) 943-961.

Holthausen, R. \& R. Watts (2001) The relevance of the value relevance literature for financial accounting standard setting. Journal of Accounting and Economics, 31(1) 3-75.

Jeong, S. W. (2003). Factors associated with analyst following and forecast characteristics. Korean Accounting Review, 28(4) 6184.

Jeong, S. W., J. B. Kim \& T. K. Lim (2006). The association between analysts' earnings forecast and stock recommendations, and the business group affiliation of analysts and forecasted firms. Accounting and Auditing Journal, 44, 27-55.

Kang, S., J. O'Brien, \& K. Sivaramakrishnan (1994). Analysts' interim earnings forecasts: Evidence on the forecasting process. Journal of Accounting Research, 32(1) 103-112.

Kim, S. J., J. H. Kim, Y. H. Woo, W. H. Lee, B. S. Jang \& M. J. Cha. (2009). Capital Market in Korea. Samyoung Press.

Klein, A. (1990). A direct test of the cognitive bias theory of share price reversals. Journal of Accounting and Economics, 13(2) 155-166.

Lee, Y. W. \& W. S. Jeong (1993). Firm characteristics and the accuracy of a financial analysts' forecasts. Korean Accounting Review, 17(1) 89-108.

Lin, H., \& M. McNichols (1998). Underwriting relationships, analysts' earnings forecasts and investment recommendations. Journal of Accounting and Economics, 25(1) 101-127.

Ljungqvist, A., F. Marston \& W. Wilhelm, Jr. (2006). Competing for Securities underwriting mandates: banking relationships and analyst recommendations. Journal of Finance, 61(1) 301-340.

Luo, Wei, Pingui Rao, \& Heng Yue (2010). Information risk and underwriter switching in SEOs: Evidence from China. Journal of Business Finance \& Accounting, 37(7-8) 905-928.

Michaely, R., \& K. L. Womack (1999). Conflict of interest and the credibility of underwriter analyst recommendations. Review of Financial Studies, 12(4) 653-686.

Petersen, M. A. (2009). Estimating standard errors in finance panel data sets: Comparing approaches. Review of financial studies, 22(1), 435-480.

Watts, R. L. (2003a). Conservatism in Accounting Part I: Explanations and Implications. Accounting Horizons, 17(3) 207-221. 


\section{NOTES}

